\title{
THE IMPACTS OF OUTDOOR GYMS ON LEISURE PHYSICAL ACTIVITY IN CAMPO GRANDE/MS
}

\author{
J. V. P. DA SILVA ${ }^{1}$, V. A. A. ANJOS ${ }^{2}$ \\ Universidade Federal de Mato Grosso do Sul \\ ORCID ID: https://orcid.org/0000-0002-4098-9664 ${ }^{1}$ \\ jr_lazer@yahoo.com.br ${ }^{1}$
}

Submetido 20/05/2020 - Aceito 28/09/2020

DOI: $10.15628 /$ holos. 2020.10180

\section{ABSTRACT}

Outdoor Gyms (OGs) are spaces adopted in municipal public policies aimed at leisure physical activity. Considering the possible benefits of adopting a physically active lifestyle, this study aimed to assess the impacts of OG on leisure physical activity. Specifically, it aimed to: diagnose the profile of users; investigate the spaces used; evaluate the reasons that lead users to attend; identify the factors which act as barriers. This is a cross-sectional, descriptive/exploratory and field study investigating municipal documents and OG users located in Campo Grande/MS. The sample consisted of 275 subjects. The technique used was document analysis and structured interviews. The results indicate a predominance of females, aged 41-60 years, and married marital status. OGs are the main spaces used for leisure, having a positive impact on adherence to physical activity of $97 \%$. Aspects related to health improvement are the main motivators for use and the absence of guidance is the biggest demotivator. It is concluded that although they positively impact the practice of leisure-time physical activity, the lack of guidance by Physical Education teachers is inhibiting.

KEYWORDS: Public Gyms, Health Promotion, Public Policy

\section{IMPACTOS DE ACADEMIAS AO AR LIVRE NA ATIVIDADE FÍSICA DE LAZER EM CAMPO GRANDE/MS}

\section{RESUMO}

As Academias ao Ar Livre (AAL) são espaços adotados em políticas públicas municipais voltadas à atividade física de lazer. Considerando os possíveis benefícios na adoção de um estilo de vida fisicamente ativo, a pesquisa teve por objetivo avaliar os impactos das AAL na atividade física de lazer. Especificamente, objetivou diagnosticar o perfil dos usuários; investigar os espaços utilizados; avaliar os motivos que levam os usuários a frequentar; identificar os fatores que atuam como barreiras. Do tipo transversal, descrito/exploratório e levantamento de campo, foram investigados documentos municipais e usuários de $A A L$ localizadas em Campo Grande/MS. A amostra foi composta por 275 sujeitos. A técnica utilizada foi a análise documento e entrevista estruturada. Os resultados indicam predominância do sexo feminino, faixa etária 41-60 anos, estado civil casado. As AAL figuram como principais espaços usados para o lazer, impactando positivamente na adesão da atividade física em $97 \%$. Aspectos relacionados a melhora da saúde são os principais motivadores ao uso e a ausência de orientação, o maior desmotivador. Conclui-se que embora impactem positivamente na prática de atividade física no lazer, a falta de orientação por professores de Educação Física figura inibidor.

PALAVRAS-CHAVE: Academias Públicas, Promoção da Saúde, Política Pública. 


\section{INTRODUCTION}

Public gyms had their first implantations in Brazil at the beginning of the $21^{\text {st }}$ century, especially in the city of Recife, which created a policy in 2007 aimed at promoting health and including the City Gym Program (PAC) among the initiatives. As the objectives, it established stimulating the practice of regular physical exercise by the citizens of Recife, to develop and stimulate spaces for social inclusion, to carry out actions and events aimed at continuing education in the health of the general public to include regular physical activity as an important factor in the development of public health policies and to promote integrated actions with others developed within the scope of the Municipal Health Secretariat ((Prefeitura Municipal de Recife, 2003).

The PAC model was followed by Belo Horizonte (Costa et al., 2013) and Aracajú (Mendonça, Toscano, \& Oliveira, 2009) and served as a basis within the scope of the National Healthcare Programming Policy (PNPS) and the National Primary Healthcare Policy (PNAB) for the creation of the Health Gym Program (PAS) and its insertion in the Unified Health System (SUS).

The program characterized public spaces being established with the objective to contribute to promoting health based on establishing centers with infrastructure, equipment and qualified staff to guide body practices and physical and leisure activities and healthy lifestyles Ministério da Saúde do Brasil, 2011a). The program objectives were reformulated in 2013, and expanded to contribute to health promotion and to produce care and healthy lifestyles for the population (Ministério da Saúde do Brasil, 2013), which was a national landmark in the discussions on health promotion actions in primary healthcare, creating new possibilities to meet and approach users (Sa et al., 2016).

In addition to financial transfers to the municipalities for installing equipment and maintenance costs ((Ministério da Saúde do Brasil, 2011b), it established the promotion of bodily practices and physical activities and guidance for the practice of physical activities as actions to be developed in its structure (Ministério da Saúde do Brasil, 2011a).

Based on the dissemination of powers and authorities which guide the SUS, the municipal executive established the competence to assign land for construction of the poles close to Basic Health Units (UBS) to complement values exceeding those established for construction and registration in the National Health Agency Fund ((Ministério da Saúde do Brasil, 2011c).

Campo Grande - MS did not join the PAS and opted for the OGs as a public leisure space aimed at promoting health. This particular model of public gyms was institutionalized in the state capital in 2006 with the "Viver Legal" Program developed by the Municipal Health Department and in 2010 through the "Movimenta Academia ao Ar Livre" Program, linked to the Municipal Sports Foundation (Prefeitura Municipal de Campo Grande, 2011).

The "Viver Legal" Program aimed to promote an improvement in the population's quality of life and the "Movimenta Academia ao Ar Livre Program" established the objective of adequately guiding practitioners of leisure-time physical activities on devices so that they can be used efficiently, impacting the possible benefits to the population and monitoring/guiding users for 
autonomy in attending these spaces without the presence of a Physical Education instructor (Prefeitura Municipal de Campo Grande, 2011).

Considering the possible contributions that the provision of public spaces can give to the practice of physical activities and social interaction, as well as the benefits to health promotion, the present investigation aimed to assess the impact of OGs on the practice of leisure physical activities. Specifically, it aimed to: diagnose the profile of users; investigate the spaces used to practice physical activities during leisure; evaluate the reasons which lead users to attend; and investigate the factors which act as barriers.

\section{METHODOLOGY}

This is a cross-sectional, quali-quantitative, descriptive-exploratory and field study (Gil, 1999). The study objects were municipal documents which guide the sport and health policy of Campo Grande - MS and the population and users of OGs existing in the seven regions of the municipality (Anhanduizinho, Bandeira, Centro, Imbirussu, Lagoa, Prosa and Segredo).

The documents were the Municipal Partnership Program Bulletin (Campo Grande City Hall, 2011), the Movimenta Program (Prefeitura Municipal de Campo Grande, 2011), Leisure and Citizenship Project (Fundação Municipal de Esportes, 2018) and Mapping of Public Facilities Outdoor Gyms (Sistema Municipal de Indicadores de Campo Grande, 2019).

The sample of users was composed of 275 subjects from the 7 regions of the municipality selected at random. The inclusion criteria were: a) being an OG user in the city; $b$ ) be present at one of the investigated OGs on the data collection day and time; $c$ ) accepting to participate in the study by signing the Informed Consent Form (ICF). The exclusion criteria were: a) being under 18; b) not accepting to participate in the study; c) refusing to sign the ICF.

The data collection was structured in two phases using diversified techniques and instruments: 1) Document analysis; 2) Structured interview.

The document analysis took place in the months of August and October 2017. The content analysis technique was adopted for the documents, which enables systematically detailing the body of textual material collected through questionnaires or interviews in order to unveil and quantify the information of words, phrases or themes considered key to solving the problem under study (Coutinho, 2014). The analysis was carried out in three phases: pre-analysis (first contact with the data), material exploration (coding, clipping and choosing recording units; enumeration, choice of counting rules and classification by category; and data processing (interpretation of results) (Gil, 1999). We used absolute and relative frequency analysis and have presented the results in figures and tables.

The interviews with users took place in February, March and April 2018 through visits in the morning, afternoon and evening periods to the 58 OG centers in Campo Grande - MS. Users were selected randomly, and those who met the inclusion criteria and agreed to participate were read the interview questions by the researcher and the responses verbalized by the users were then 
registered on the form. The average time of each interview per user was 20 minutes. The data obtained were subjected to analysis of relative and absolute frequency.

We prepared a form composed of open-ended questions for a structured interview which was specifically created for the research objectives, with four questions related to demographic data, two regarding the use of OGs (In addition to OGs, do you do physical leisure activities in other places? If they answered yes, inform the location), and three on the impacts (Does the existence of OGs encourage you to practice physical activities in your leisure time? Why? What factors make it difficult for you to use this space more?). The instrument was tested in a pilot study before applying it to the sample in order to train the researcher and adjust the instrument. The questions were read by the researcher and the answers recorded in a digital voice recorder, Blue, recording up to 4405 minutes.

The study was submitted to evaluation by the Ethics Committee in research with human beings, following the recommendations of Resolution No. 466, of December 12, 2013 and Resolution No. 510, of April 7, 2016, of the National Health Council, with approval by Research Ethics Committee of the Federal University of Mato Grosso do Sul under opinion No. 2,148,816/2017.

\section{RESULTS}

The OG users are predominantly female, between 41 and 60 years old and are married (Table 1). Most have been attending the OGs for more than a year (one to three years), two to three days a week, with a stay of 40 to 60 minutes.

Table 1: User profile and usage pattern of OGs administered by the Municipality of Campo Grande - MS ( $n=275)$.

\begin{tabular}{lcc}
\hline & \multicolumn{2}{c}{ Frequency } \\
& Absolute & Relative \\
\hline Gender & 193 & $70.18 \%$ \\
Female & 82 & $29.81 \%$ \\
Male & & \\
Age & 46 & $16.72 \%$ \\
18-40 years & 122 & $44.31 \%$ \\
41-60 years & 107 & $38.96 \%$ \\
Over 60 years & & \\
Civil status & 29 & $10.54 \%$ \\
Single & 137 & $49.81 \%$ \\
Married & 65 & $23.63 \%$ \\
Divorced & 44 & $16.02 \%$ \\
Widower & & \\
Usage time & 91 & $33.10 \%$ \\
Less than 1 year & 101 & $36.72 \%$ \\
1 to 3 years & 53 & $19.27 \%$ \\
4 to 6 years & 30 & 10.91 \\
More than 6 years & & \\
Weekly frequency & & $0.72 \%$ \\
1 day & 2 & $48.72 \%$ \\
2 to 3 days & 134 & $44.01 \%$ \\
4 to 5 days & 121 &
\end{tabular}

HOLOS, Ano 36, v. 6, e10180, 2020 


\begin{tabular}{lcc}
6 to 7 days & 18 & $6.55 \%$ \\
$\begin{array}{l}\text { Average time spent } \\
\text { Up to } 10 \text { minutes }\end{array}$ & 2 & 0.72 \\
11 to 30 minutes & 101 & $36.72 \%$ \\
31 to 39 minutes & 3 & $1.09 \%$ \\
40 to 60 minutes & 155 & $56.38 \%$ \\
Over 60 minutes & 14 & $5.09 \%$ \\
\hline Source: Research data. & &
\end{tabular}

The predominance of females among users contradicts national surveys which observed a greater participation of men (Brasil, 2019) or international studies which showed similarity among users of fitness centers (Estrada-Marcén, Sanz-Gonzalo, Simón-Grima, Casterad-Seral, \& RosoMoliner, 2019).

However, when considering the specificity of the research locations in our study (OGs), the greater adherence of women in Campo Grande, MS, corroborates studies developed with users of this same type of gym (Costa, Freitas, \& Silva, 2016, Souza, Fermino, Añez, \& Reis, 2014), as well as other public gyms - PAC (Fernandes et al., 2017, Hallal et al., 2010, Lemos, Bastos, Silva, Luna, \& Gouveia, 2016).

The greater involvement of women in the practice of physical activity in public gyms may be related to cultural constructions which typify specific actions for women and men, and thus stigmatize social functions and activities, with leisure activities among them.

In particular regarding leisure experiences (games, games, sports and physical activities), female participation was historically restricted to the residential space, while boys enjoyed games in the streets and neighborhood. Sports activities which require greater physical vigor were encouraged for men. However, only the lightest and most aesthetic were in turn encouraged for women. According to Vera et al. (2018), childhood perceptions that competitive physical activities and contact (boxing, rugby, karate) are more appropriate for boys are established, which corroborates maintaining stereotypes.

In spite of small advances occurring against this theme in Brazil, gender issues still act strongly on leisure experiences, with more female participation in dance and ballet practice, rhythmic and artistic gymnastics, walking and fitness, while football, cycling, fighting and martial arts and athletics are more male activities. Fitness/gym is the most, with percentages of adherence in this type of physical activity higher than those found among men (IBGE, 2017).

OGs are the main space for users to practice physical activities. However, a considerable percentage also use conventional parks and gyms. Regarding the importance of the OGs, 97\% indicated that they positively impact their adherence to leisure-time physical activity (Figure 1). 


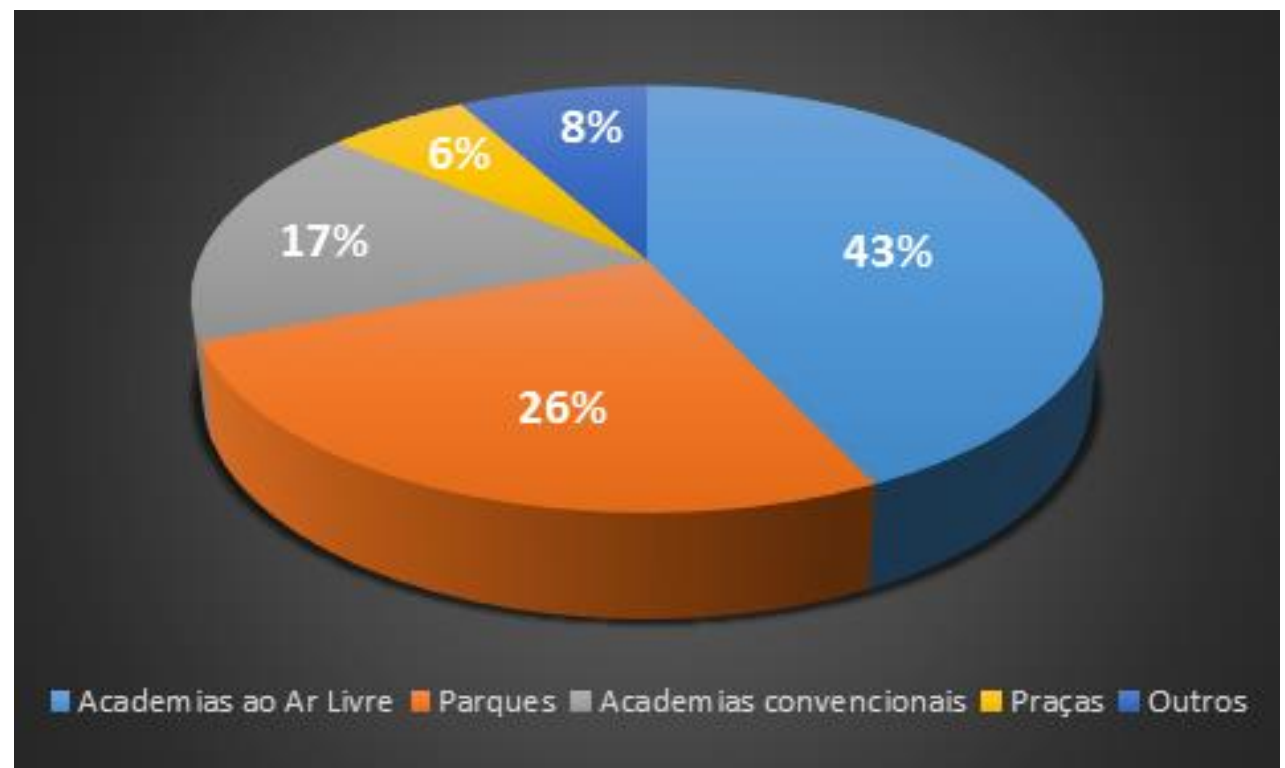

Figure 1: Spaces used for leisure-time physical activity practices by OG users in Campo Grande - MS (n= 275).

Source: Research data.

The implementation of policies aimed at promoting physical activities in OGs is configured as an enhancement strategy within the scope of the municipal administration to face physical inactivity and health promotion in Campo Grande, MS, as it has good adherence and its existence had a positive impact on the population's decision to practice physical exercises using the equipment which are at the OGs.

The strategy of using public gyms as a promoter of physical activities has also been evidenced at the regional and national levels. Belo Horizonte has developed $P A C$ together with PAS units since 2005. It had 76 centers in 2016 (Fernandes et al., 2017). Pernambuco had 276 hubs located in 146 municipalities in 2014 (Lemos, Bastos, Silva, Luna, \& Gouveia, 2015). OG totals 7,500 installations in Brazil, present in 2,000 municipalities (Souza et al., 2014). PAS is present in 2,678 cities, with 3,821 installed centers (Brasil, 2018).

The implantation of spaces is appreciated by the population, since most of them indicated attending OGs from one to three years. The permanent use of public gyms has shown an average of 25 months (Lemos et al., 2016), 27.5 months (Mathias et al., 2019) and 36 months (Fernandes et al., 2017), which indicates user satisfaction, because according to Pascual, ALguacil e Garcia (2020), user loyalty is statistically related to the satisfaction promoted by the space.

The positive impacts and user satisfaction indicate how necessary the social policies aimed at democratizing access to public spaces for leisure and health promotion, especially for populations with less economic power. The Brazilian population with no income or income below one minimum monthly salary are those who least practice sports and physical activities (IBGE, 2017), which is related to environmental factors such as the lack of public spaces (Vieira \& Silva, 2019).

Despite the advances which have occurred with the creation of the "Movimenta Academia ao Ar Livre" and "Viver Legal" Program and implementation of OG, the performance of the municipal 
management is still insufficient, since Campo Grande, MS has 53 hubs for 73 neighborhoods. Such a reality signaled the importance of expanding the centers of public academies in order to include those neighborhoods which do not yet have them.

The market becomes the main promoter of the practice of physical activities aimed at health promotion in the absence or insufficient action of the State, which is only available to a portion of the population. Demographic data indicate private sports facilities as the main places used by Brazilians for sports (IBGE, 2017), with the value of the monthly fee varying in the choice (Welter, Neves, \& Saavedra, 2017). Subjects of socioeconomic level D/E were $80 \%$ less likely to have practiced or go to practice physical activities in private gyms (Silva, Rombaldi, Azevedo, \& Hallal, 2008).

If there is no State intervention, which the main level responsible via positive law for promoting public policies (Dye, 2010), part of the population is not assisted in having the constitutional rights to health and leisure ensured, which is contradictory as they are precisely people in the lower socioeconomic class who are the main users of programs created to practice physical activities (Ferreira et al., 2019).

Health-related issues (improving health and maintaining health) are the main factors that motivate users to attend OGs. They particularly use these spaces to enjoy health benefits (Table 2).

Table 2: Reasons for joining the OGs to practice leisure-time physical activities in Campo Grande - MS - 2018 $(n=275)$.

\begin{tabular}{lcc}
\hline \multicolumn{1}{c}{ Reasons } & \multicolumn{2}{c}{ Frequency } \\
& Absolute & Relative \\
\hline Improve health & 61 & $22.76 \%$ \\
Maintain health & 50 & $18.65 \%$ \\
Proximity & 34 & $12.68 \%$ \\
Ease of access & 28 & $10.44 \%$ \\
Socialization & 25 & $9.32 \%$ \\
Financial accessibility & 24 & $8.95 \%$ \\
Being outdoors & 22 & $8.20 \%$ \\
Stimulation by third parties & 9 & $3.35 \%$ \\
The idea of the OG & 6 & $2.23 \%$ \\
Stimulus for existence & 5 & $1.86 \%$ \\
Receive guidance & 4 & $1.49 \%$ \\
\hline Source: Research data. & \multicolumn{2}{l}{}
\end{tabular}

The democratization of access to OGs is relevant to health promotion, as this was the main reason for users to attend them. Health promotion (adopting a healthy lifestyle) was also highlighted as the main reason for using the PAC in Recife (Lemos et al., 2016) and OGs in Paranaguá - PR (Mathias et al., 2019).

There is evidence that the use of public gyms motivated by health improvement has obtained positive results when considering the international recommendations for practicing physical activities. As in the example observed in Campo Grande, the frequency and duration are higher than three times a week and to 60 minutes per day (Hallal et al., 2010; Lopes et al., 2016; Mathias et al., 
2019), which meets the minimum parameters (150 minutes per week, at a moderate level) established as being necessary for promoting health (Who, 2014).

Practicing leisure-time physical activities mediated by regular attendance can result in improvements in physical and psychological aspects ranging from decreasing physical pain to increasing self-esteem and disposition. It promotes stress reduction and recurrent anxiety due to the increase in endorphins, as well as improvement in blood vessel dilation and strengthening, resulting in blood pressure regulation (Warbuton, Nicol, \& Bredin, 2006).

However, the benefits of policies for spaces for experiencing physical activities go beyond those resulting from energy expenditure. Based on an expanded understanding of health, we believe that the importance of these spaces as health promoters overflows to benefits in other dimensions, since they also corroborate socialization and collective coexistence.

This reality was evidenced with the participants in the present research who pointed out socialization as one of the main reasons for use. In Curitiba, PR, OG users pointed out that they always met people they knew or made new friends (Souza et al., 2014). In addition to becoming more physically active and showing health improvements when compared to non-users, it became evident in Belo Horizonte, MG, that participation in the program increased social contact with neighbors (Fernandes et al., 2017).

The creation of cities for people and promoting social relations for all means providing adequate, quality and inviting conditions for the population to remain in the place, which only occurs if the space is beautiful, significant or pleasant (Gehl, 2013). The public space must appear as a mechanism for social redistribution, community cohesion, a space for political formation, for the expression of collective wills and conflicts (Borja, 2010).

As observed with OG users in Campo Grande, a positive relationship between proximity of spaces to residential areas has been evidenced in Brazilian literature (Hallal et al., 2010), with a statistically significant relationship with leisure walking when two spaces are within 500 meters of the residence (Florindo et al., 2017). On the other hand, uneven distribution which often favors central regions to the detriment of the periphery corroborates that the opportunities for access are lower (Marcellino, Barbosa, Mariano, Silva, \& Fernandes, 2007).

Despite the majority of the results indicating adherence to practicing physical activities motivated by improvements in health and even knowing the importance of a physically active lifestyle, part of society has possibilities to enjoy leisure living spaces due to the negative effects of factors which act as barriers; barriers which are complex and manifest in several domains, including the social by which a lack of guidance is inserted, and figured as the main demotivator to users to attend OGs in Campo Grande in the present study. 


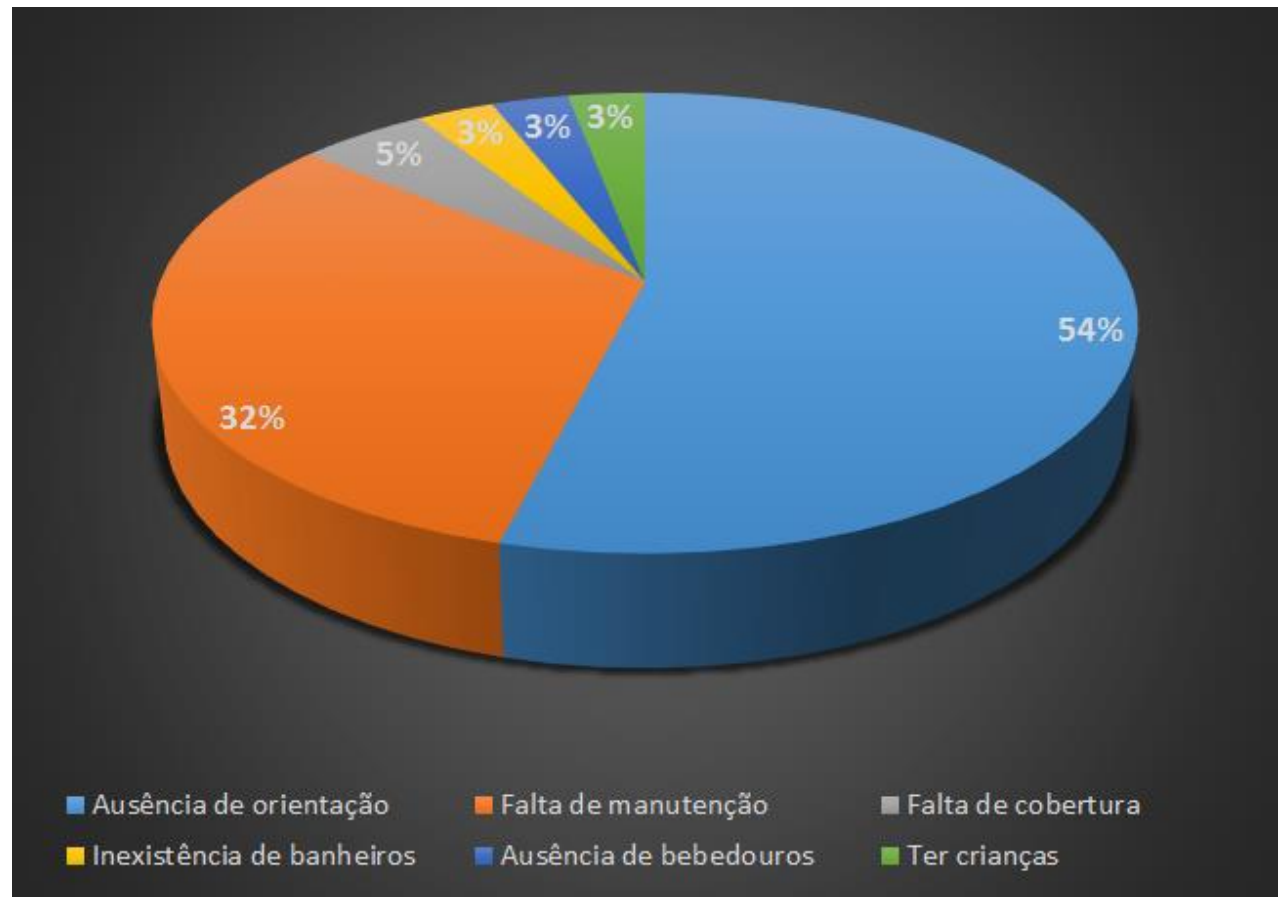

Figure 2: Barriers presented by OG users to practice physical activities during leisure time ( $n=275)$. Source: Research data.

It is noted that in addition to the equipment construction, public policies aimed at health promotion must also pay attention to the importance of providing professionals with specific training to guide users, as this was pointed out by users as the main barrier.

The presence of Physical Education teachers in OGs who are part of the "Movimenta Academia Ao Livre" Program in order to better serve and guide users is essential for the program's effectiveness and efficiency, as the outlined objective is to properly guide practitioners of leisuretime physical activities on the devices so that they can be used efficiently, impacting the population with possible benefits and accompanying/guiding users towards autonomy in attending these spaces without the presence of the Physical Education teacher, which in turn would indicate that the program at least partly did not adequately achieve the objectives it proposed.

A deficient performance of Physical Education teachers has been evidenced in municipal OG programs in other Brazilian locations. For example, only $23 \%$ received instruction during practice in Florianópolis, SC, while 31.3\% did not know how to use the devices and $69 \%$ need guidance (Costa et al., 2016). In the extreme south of Brazil, only $16.11 \%$ used physical education services. Of those who used it, access was through private services (78\%), especially fitness centers (73\%) (Oliz, Dumith, \& Knuth, 2020). A different condition is evident in the PAS (Silva et al., 2016; Florindo et al., 2016), in which there is a predominance of Physical Education teachers among professionals.

This stems from the mandatory availability of human resources in the PAS being regulated by article 12 of Ordinance No. 2,681, of November 2013, which establishes that professionals in Primary Healthcare who work in the Family Health Strategy and Family Health Support Centers are those who should be responsible for developing activities in the PAS (Ministério da Saúde do Brasil, 2013). 
Despite advances and contributions from standardizing Physical Education professionals in the PAS, the limitations of municipal resources to fund trained professionals, among others, have figured as one of the main barriers to implementing and maintaining the system (Mota, Viana, \& Bousquat, 2016).

The absence of Physical Education professionals to provide guidance on the use of OG devices with which users then perform the exercises on their own and may make mistakes, thereby resulting in negative effects such as injuries. Understanding through guidance which muscle group each device works reflects in conscious practice, in which the individuals themselves can track their limitations regarding their body, corroborating the autonomy to practice physical activities at leisure. Still, the presence of the professional promotes well-being to users to perform the exercises safely, as well as motivation through encouraging them and creating an environment close to health promotion from an expanded perspective, which in addition to the objective effects of physical activity to functional aspects, also adds subjective elements related to emotional, social and environmental aspects.

It is necessary to expand municipal public policies to advance health promotion, as well as greater scope of PAS policy in Brazil as public gyms are a unique opportunity for democratizing access to spaces to practice physical activities, which can in turn lead to an increase in the number of people who choose to occupy their available time with this type of activity, especially those of low socioeconomic class and who cannot afford a private gym.

\section{CONCLUSIONS}

It is concluded that OGs positively impact the leisure activity of users in the evaluated spaces. Health promotion is the main factor which motivates the use of these spaces. However, they are insufficient since users also resort to other spaces, especially squares and parks. A lack of Physical Education teachers to provide guidance on the use of devices is the main barrier to greater use.

It is important to expand municipal public policies, as well as to expand the scope of PAS policy in Brazil, as public academies are a unique opportunity to democratize access to physical activity spaces, which may corroborate with the expansion the number of people who choose to occupy their available time with this type of activity, especially those of low socioeconomic class and who are unable to afford a private gym.

\section{REFERÊNCIAS}

Brasil (2018). Panorama nacional de implementação do Programa Academia da Saúde: monitoramento do Programa Academia da Saúde: ciclo 2017. Brasília: Ministério da Saúde.

Brasil (2019). Vigitel Brasil 2018: vigilância de fatores de risco e proteção para doenças crônicas por inquérito telefônico: estimativas sobre frequência e distribuição sociodemográfica de fatores de risco e proteção para doenças crônicas nas capitais dos 26 estados brasileiros e no Distrito Federal em 2018. Brasília: Ministério da Saúde, 2019. 
Borja, J. (2010). La ciudade conquistada. Madrid. Alianza editorial.

Costa, B. V. de L., Mendonça, R. D., Santos, L. C., Peixoto, S. V., Alves, M., \& Lopes, A. C. S. (2013). Academia da Cidade: um serviço de promoção da saúde na rede assistencial do Sistema Único de Saúde. Revista Ciência \& Saúde Coletiva, 18(1), 95-102.

Costa, B. G. G., Freitas, C. D. L., \& Silva, K. S. (2016). Atividade física e uso de equipamentos entre usuários de duas Academias ao Ar Livre. Rev Bras Ativ Fís Saúde, 21(1), 29-38. https://doi:10.12820/rbafs.v.21n1p29-38

Coutinho, C. P. (2014). Metodologia de investigação em ciências sociais e humanas: teoria e prática. Coimbra: Almedina.

Dye, T. (2010). Mapeamento dos modelos de análise de políticas públicas. In: Heidemann, F., \& Salm, J. F. (Orgs.). Políticas públicas e desenvolvimento: bases epistemológicas e modelos de análise. Brasília: Editora Universidade de Brasília, p. 99-129.

Estrada-Marcén, N. C., Sanz-Gonzalo, G., Simón-Grima, J., Casterad-Seral, J., \& Roso-Moliner, A. (2019). Los centros de fitness de la ciudad de Zaragoza. Apunts. Educación Física y Deportes, 135, 118-136. https://doi.org/10.5672/apunts.2014-0983.es.(2019/1).135.08

Fernandes, A. P., Andrade, A. C. S., Costa, D. A. S., Dias, M. A. S., Malta, D. C., \& Caiaffa, W. T. (2017). Programa Academias da Saúde e a promoção da atividade física na cidade: a experiência de Belo Horizonte, MG, Brasil. Ciência \& Saúde Coletiva, 22(12), 3903-3914. https://doi:10.1590/1413-812320172212.25282017

Ferreira, R. W., Caputo, E. L., Häfele, C. A., Jerônimo, J. S., Florindo, A. A., Knuth, A. G., \& Silva, M. C. (2019). Acesso aos programas públicos de prática de atividade física no Brasil: Pesquisa Nacional de Saúde, 2013. Cad. Saúde Pública, 35(2), e00008618. https://doi:10.1590/0102$311 \times 00008618$

Florindo, A. A., Barrozo, L. V., Cabral-Miranda, W., Rodrigues, E. Q., Turrell, G., Goldbaum, M., Cesar, C. L. G., \& Giles-corti, B. (2017). Public Open Spaces and Leisure-Time Walking in Brazilian Adults. Int J Environ Res Public Health, 14(6), 1-12. https://doi:10.3390/ijerph14060553

Florindo, A. A., Nakamura, P. M., Farias Júnior, J. C., Siqueira, F. V., Reis, R. S., D. K. A., \& Hallal, P. C. (2016). Promoção da atividade física e da alimentação saudável e a saúde da família em municípios com academia da saúde. Rev Bras Educ Fís Esporte, 30(4), 913-24. https://doi.org/10.1590/1807-55092016000400913

Fundação Municipal de Esportes (2016). Programa Movimenta. https://www.campogrande.ms.gov.br/funesp/artigos/movimenta-campo-grande

Fundação Municipal de Esportes (2018). Projeto Lazer e Cidadania. http://www.campogrande.ms.gov.br/funesp/projeto-lazer-e-cidadania

Gil, A. C. (1999). Métodos e Técnicas e Pesquisa Social. 5ạ. ed. São Paulo: Atlas. 
Gehl, J. (2013). Cidades para pessoas. São Paulo: Perspectiva.

Hallal, P. C., Tenório, M. C. M., Tassitano, R. M., Reis, R. S., Carvalho, Y. M., Cruz, D. K. A., Damascena, E., \& Malta, D. C. (2010). Avaliação do programa de promoção da atividade física Academia da Cidade de Recife, Pernambuco, Brasil: percepções de usuários e não-usuários. Cad. Saúde Pública, 26(1), 70-78. https://doi:10.1590/S0102-31X2010000100008

IBGE. Práticas de esporte e atividade física: 2015/IBGE, Coordenação de Trabalho e Rendimento. Rio de Janeiro: IBGE, 2017.

Lemos, E. C., Bastos, L. L. A. C., Silva, G. B., Luna, C. F., \& Gouveia, G. C. (2016). Factors associated with adherence to the academia da cidade Program in Recife. Rev Bras Ativ Fís Saúde, 21(5), 470-482. https://doi:10.12820/rbafs.v.21n5p470-48

Lemos, E. C., Paes, I. M. B. S., Abath, M. B., Brainer, M. G. F., \& Lima, J. I. A. F. (2015). Monitoramento do Programa Academia das Cidades e da Saúde: a experiência de Pernambuco. Rev Bras Ativ Fís Saúde, 20(2), 203-207. https://doi.org/10.12820/rbafs.v.20n2p203

Lopes, A. C. S., Ferreira, A. D., Mendonça, R. D., Dias, M. A. S., Rodrigue, R. C. L. C., \& Santos, L. C. (2016). Estratégia de Promoção à Saúde: Programa Academia da Cidade de Belo Horizonte. Rev Bras Ativ Fís Saúde, 21(4), 379-384. https://doi:10.12820/rbafs.v.21n4p379-384

Marcellino, N. C., Barbosa, F. S., Mariano, S. H., Silva, A., \& Fernandes, E. A. de O. (2007). Espaços e Equipamentos de Lazer em Região Metropolitana. Campinas: Opus.

Mathias, N. G., Melo Filho, M., Szkudlarek, A. C., Gallo, L. H., R. C., Fermino, A., \& Gomes, A. R. S. (2019). Motivos para a prática de atividades físicas em uma academia ao ar livre de ParanaguáPR. Rev Bras Ciênc Esporte, 41(2), 222-228. https://doi.org/10.1016/j.rbce.2018.03.030

Mendonça, B. C. de A., Toscano, J. J. de O., \& Oliveira, A. C. C. (2009). Do diagnóstico à ação: experiências em promoção da atividade física programa Academia da Cidade Aracaju: promovendo saúde por meio da atividade física. Revista Brasileira de Atividade Física \& Saúde, 14(3), 211-2016. https://doi.org/10.12820/rbafs.v.14n3p211-216

Ministério da Saúde do Brasil (2011a, 7 de abril). Portaria no 719. Institui o programa academia da saúde no âmbito do sistema único de saúde. https://bvsms.saude.gov.br/bvs/saudelegis/gm/2011/prt0719 0704 2011.html

Ministério da Saúde do Brasil (2011c, 15 de junho). Portaria no 1.401. Institui, no âmbito da Política Nacional de Atenção Básica, o incentivo a construção de polos da Academia da Saúde. https://bvsms.saude.gov.br/bvs/saudelegis/gm/2011/prt1401_15 06_2011.html

Ministério da Saúde do Brasil (2011b, 15 de junho). Portaria no 1.402. Institui, no âmbito da Política Nacional de Atenção Básica e da Política Nacional de Promoção da Saúde, os incentivos para custeio das ações de promoção da saúde do Programa Academia da Saúde. http://bvsms.saude.gov.br/bvs/saudelegis/gm/2011/prt1402_15_06 2011.html 
Ministério da Saúde do Brasil (2013, 7 de novembro). Portaria no 2.681. Redefine o programa academia da saúde no âmbito do Sistema único de Saúde (SUS). https://bvsms.saude.gov.br/bvs/saudelegis/gm/2013/prt2681 0711 2013.html

Mota, P. H. S., Viana, A. L., \& Bousquat, A. (2016). Relações federativas no Programa Academia da Saúde: estudo de dois municípios paulistas. Saúde debate, 40(108), 64-73. https://doi:10.1590/0103-1104-20161080005SAÚDE

Oliz, M. C., Dumith, S. C., \& Knuth, A. G. (2020). Utilização de serviços de educação física por adultos e idosos no extremo sul do Brasil: estudo de base populacional. Ciência \& Saúde Coletiva, 25(2), 541-552. https://doi:10.1590/1413-81232020252.14692018

Pascual, F. G., Alguacil, M., \& García, N. M. (2020). Predicción de la lealtad de los usuarios de centros deportivos privados. Variables de gestión y bienestar subjetivo. Retos, 38, 16-19. Pereira, L. G., Fernández

Prefeitura Municipal de Campo Grande (2011). Informativo do Programa de Parceria Municipal. https://www.campogrande.ms.gov.br/planurb/wpcontent/uploads/sites/18/2017/01/201109 30145045.pdf

Prefeitura Municipal de Recife (2003, 3 de abril). Decreto 19.808. Institui e regulamenta o Programa Academia da Cidade, da Secretaria Municipal de Saúde. http://www.legiscidade.recife.pe.gov.br/decreto/19808

Sá, G. B. A. R., Dornelles, G. C., Cruz, G. D., Amorim, R. C. A., Andrade, S. S. C. A., Oliveira, T. P., Silva, M. M. A., Malta, C. C., \& Souza, M. F. M. (2016). O Programa academia da Saúde como estratégia de promoção da saúde e modos de vida saudáveis: cenário nacional de implementação. Ciência \& Saúde Coletiva, 21(6), 1849-1859.

Sistema Municipal de Indicadores de Campo Grande. Equipamentos públicos. Academias ao Ar Livre. 2019. http://sisgran.campogrande.ms.gov.br/mapas/\#15/-20.4863/-54.5081

Silva, J. R. A., Lemos, E. C., Wanderley, R. S. J., Santos, S. J., Silva Junior, A. G., \& Barros, M. G. (2016). Monitoramento e avaliação nas intervenções de atividade física na Atenção Básica de Pernambuco. Rev Bras Ativ Fís Saúde, 21(5), 431-44. https://doi:10.12820/rbafs.v.21n5p431$\underline{441}$

Silva, M. C., Rombaldi, A. J., Azevedo, M. R., \& Hallal, P. C. (2008). Participação atual e passada em academias de ginástica entre adultos: prevalência e fatores associados. Revista Brasileira de Atividade Física, 13(1), 28-36.

Souza, C. A., Fermino, R., Añez, C., \& Reis, R. (2014). Perfil dos frequentadores e padrão de uso das academias ao ar livre em bairros de baixa e alta renda de Curitiba- PR. Revista Brasileira de Atividade Física e Saúde, 19(1), 86-97. https://doi.org/10.12820/rbafs.v.19n1p86

Vera, J. G., Arrebola, I. A., \& Garcia, N. A. Género y relación con la práctica de la actividad física y el deporte. Apunts. Educación Física y Deportes, 132, 123-141. https://doi.org/10.5672/apunts.2014-0983.es.(2018/2).132.09 
Vieira, V. R., \& Silva, J. V. P. (2019). Barreiras à prática de atividades físicas no lazer de brasileiros: revisão sistematizada. Pensar a prática, 22, 1-22. https://doi.org/10.5216/rpp.v22.54448

Warbuton, D., Nicol, C. W., \& Bredin, S. (2006). Health benefits of physical activity: the evidence. Canadian Medical Association Journal, 174(6), 801-808. https://10.1503/cmaj.051351

Welter, D. L., Neves, E. B., \& Saavedra, F. J. F. (2017). Profile of practitioners of supervised physical exercise in the southern region of Brazil. Biosci. J., 33(1), 209-218. http://orcid.org/0000-0003$\underline{4507-6562}$

Who (2014). Global status report on noncommunicable diseases 2014. Geneva: World Health Organization.

\section{COMO CITAR ESTE ARTIGO:}

Silva, J. V. P. DA., Anjos, V. A. A. (2020). The impacts of outdoor gyms on leisure physical activity in Campo Grande/MS. Holos. 36(6), 1-14.

\section{SOBRE OS AUTORES}

\section{J. V. P. DA SILVA}

Doutor em Educação Física pela Universidade Católica de Brasília e docente do curso de Educação Física e Programa de Pós-graduação em Saúde e Desenvolvimento do Centro Oeste, desenvolve estudos relacionados a políticas públicas de esporte, lazer e promoção da saúde. É presidente da Associação Brasileira de Pesquisa e Pós-graduação e Estudos de Lazer (2018-2020).

E-mail: jr lazer@yahoo.com.br

ORCID ID: https://orcid.org/0000-0002-4098-9664

\section{A. A. ANJOS}

Mestre em Saúde e Desenvolvimento da Região do Centro Oeste, pesquisador vinculado ao Grupo de Estudos e Pesquisas em Políticas Públicas de Esporte, Lazer e Saúde - GEPPPELS.

E-mail: vitoranjos1@gmail.com

ORCID ID: https://orcid.org/0000-0002-5086-1111

Editor(a) Responsável: Francinaide de Lima Silva Nascimento

Pareceristas Ad Hoc: Rosivalda Barreto e Alison Batista

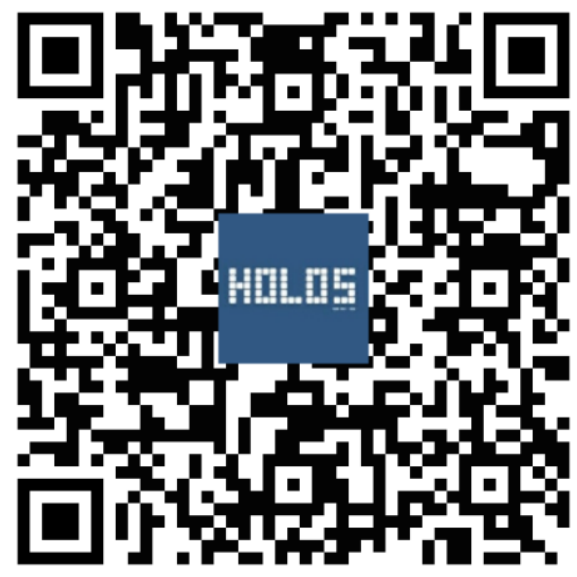

